\title{
Correction to: A network DEA aeronautical and non-aeronautical production model: an application to South Korea airports
}

\author{
Myung Je Lee ${ }^{1}$ and Changhee $\operatorname{Kim}^{2^{*}}$ (D)
}

${ }^{*}$ Correspondence:

ckim@inu.ac.kr

${ }^{2}$ College of Business

Administration, Incheon National University, 119 ,

Academy-ro, Yeonsu-gu, Incheon 22012, Republic

of Korea

Full list of author information is available at the end of the article

\section{Correction to: Economic Structures (2018) 7:32 https://doi.org/10.1186/s40008-018-0130-2}

The authors noticed accidental mistakes existing in Sects. 2 and 3 of the original article (Lee and Kim 2018). In the Sect. 2, the authors deleted some part of second paragraph since it just copied with technical mistakes in progress. And in the Sect. 3, the authors changed citation style of third paragraph. This change does not affect the conclusions and results in the original publication. The authors would like to apologize for any inconvenience which this change may have caused.

Deleted part of second paragraph in Sect. 2:

In the Sect. 2, 15th to 41st lines "Furthermore..., could not provide corresponding improvement strategies to managers." should be deleted.

Revised third paragraph in Sect. 3:

Dan Liu once claimed that "The non-aeronautical business, that is also known as commercial service usually consists of franchise-based operations and self-operations, such as ground handling agent service supplied for airliners, in-flight catering services, duty free and other retail shops in the terminals, leasing of advertising space inside and outside the terminals of the airport, provision of goods warehousing, cargo handling agent companies" (Liu 2016).

\section{Author details}

${ }^{1}$ College of Liberal Studies, Seoul National University, 1, Gwanak-ro, Gwanak-gu, Seoul 08737, Republic of Korea. ${ }^{2}$ College of Business Administration, Incheon National University, 119, Academy-ro, Yeonsu-gu, Incheon 22012, Republic of Korea.

The original article can be found online at https://doi.org/10.1186/s40008-018-0130-2.

\section{Publisher's Note}

Springer Nature remains neutral with regard to jurisdictional claims in published maps and institutional affiliations.

Published online: 03 April 2019

(2) The Author(s) 2019. This article is distributed under the terms of the Creative Commons Attribution 4.0 International License (http://creativecommons.org/licenses/by/4.0/), which permits unrestricted use, distribution, and reproduction in any medium provided you give appropriate credit to the original author(s) and the source, provide a link to the Creative Commons license, and indicate if changes were made. 


\section{Reference}

Lee MJ, Kim C (2018) A network DEA aeronautical and non-aeronautical production model: an application to South Korea airports. Econ Struct 7:32. https://doi.org/10.1186/s40008-018-0130-2

Submit your manuscript to a SpringerOpen ${ }^{\circ}$ journal and benefit from:

- Convenient online submission

- Rigorous peer review

- Open access: articles freely available online

- High visibility within the field

- Retaining the copyright to your article

Submit your next manuscript at $\boldsymbol{\nabla}$ springeropen.com 